\title{
HARPACTICOID COPEPODS ASSOCIATED WITH HERMIT CRABS IN THE MOLUCCAS
}

by

\author{
ARTHUR G. HUMES ${ }^{1)}$
}

\begin{abstract}
Paguridea in the Indo-Pacific have 10 harpacticoid copepod associates: 3 Sunaristes, 3 Brianola, 1 Porcellidium, and 3 Paraidya. Four of these copepods are reported from hermit crabs in the Moluccas: Sunaristes tranteri Hamond, 1973, from Dardanus guttatus, Dardanus lagopodes, Calcinus latens, Calcinus minutus, Calcinus gaimardi, Calcinus sp., and Trizopagurus strigatus; Porcellidium brevicaudatum Thompson and A. Scott, 1903, from Dardanus guttatus, Dardanus lagopodes, Dardanus megistos, Calcinus latens, Calcinus minutus and Trizopagurus strigatus; Paraidya minor Sewell, 1940, and Paraidya major Sewell, 1940, from Dardanus guttatus, Dardanus lagopodes, and Dardanus megistos.
\end{abstract}

\section{INTRODUCTION}

Several harpacticoid copepods live in association with hermit crabs. In Europe Sunaristes paguri Hesse, 1867, lives with Pagurus bernhardus (L.) (distribution given in Lang, 1948, and Codreanu and Mack-Fira, 1961),Pagurus cuanensis Thompson (Bourdon, in Hamond, 1973), Diogenes pugilator (Roux) (Codreanu and Mack-Fira, 1961), and Clibanarius erythroupus (Latreille) (Stock, 1960).

In the Indo-Pacific harpacticoid copepods have been reported from various Paguridea in widely scattered localities. These copepods belong to four genera - Sunaristes Hesse, 1867 (Canuellidae), Brianola Monard, 1926 (Canuellidae), Paraidya Sewell, 1940 (Tisbidae), and Porcellidium Claus, 1860 (Porcellidiidae). The records are as follows:

Sunaristes dardani Humes and Ho, 1969

region of Nosy Be, Madagascar - Humes and Ho (1969a)

from Dardanus megistos (Herbst). Dardanus deformis (H. Milne Edwards), Dardanus guttatus (Olivier), Dardanus lagopodes (Forskal), and Calcinus latens (Randall).

Mauritius - Humes and Ho (1969a)

from Dardanus deformis, Dardanus lagopodes, and from 5 hermit crabs mixed at time of collection [Dardanus setifer (H. Milne Edwards), Dardanus lagopodes, and Calcinus elegans (H. Milne Edwards)].

1) Boston University Marine Program, Marine Biological Laboratory, Woods Hole, Massachusetts 02543 . 


\section{ARTHUR G. HUMES}

Eniwetok Atoll - Humes (1971)

from Dardanus guttatus, Dardanus megistos, Dardanus lagopodes, Dardanus scutellatus (H. Milne Edwards), and Calcinus latens. region of Noumea, New Caledonia - Humes (1972)

from Clibanarius virescens Krauss, Dardanus lagopodes, and Dardanus megistos.

Sunaristes inaequalis Humes and Ho, 1969

region of Nosy Be, Madagascar - Humes and Ho (1969a)

from unidentified small hermit crabs and from Dardanus megistos.

Red Sea (Ethiopia) - Humes and Ho (1969a) from Clibanarius carnifex

Heller.

region of Noumea, New Caledonia - Humes (1972)

from Calcinus latens, Clibanarius virescens, Dardanus megistos, and Dardanus scutellatus.

Sunaristes tranteri Hamond, 1973 Sydney, Australia - Hamond (1973)

from Diogenes senex Heller.

Sunaristes sp., undescribed

Auckland, New Zealand - Hamond (1973)

from Pagurus novaezealandiae Filhol.

Brianola elegans Hamond, 1973

Sydney, Australia - Hamond (1973)

from Diogenes senex Heller.

Brianola pori Hamond, 1973

Sydney, Australia - Hamond (1973)

from Diogenes senex Heller.

Brianola sydneyensis Hamond, 1973

Sydney, Australia - Hamond (1973)

from Diogenes senex Heller.

Porcellidium breuicaudatum Thompson and A. Scott, 1903

region of Nosy Be, Madagascar - Humes and Ho (1969b)

from Dardanus megistos, Dardanus guttatus, and Dardanus lagopodes

Mauritius - Humes and Ho (1969b)

from Dardanus megistos, Dardanus guttatus, and Dardanus lagopodes. region of Noumea, New Caledonia - Humes (1972)

from Clibanarius virescens, Pagurus sp., Calcinus latens, Dardanus agopodes, Dardanus guttatus, Dardanus megistos, Dardanus deformis, and Dardanus scutellatus. 


\section{HARPACTICOID COPEPODS ASSOCIATED}

Paraidya occulta Humes and Ho, 1969

region of Nosy Be, Madagascar — Humes and Ho (1969b) from Dardanus megistos.

Two Indo-Pacific records of Sunaristes paguri Hesse, 1867, exist in the literature. Thompson and A. Scott (1903) reported a few specimens in the general washings of invertebrates in Ceylon. A. Scott (1909) found a single male in washings of dredged invertebrates near New Guinea. Both these identifications need verification, since it seems unlikely that $S$. paguri occurs in the Indo-Pacific, having never been reported in more extensive collections.

\section{MATERIALS AND METHODS}

The living hermit crabs were separated by species in plastic bags in sea water. Later a small amount of 95 per cent ethyl alcohol was added, sufficient to make approximately a 5 per cent solution. After several hours the hermit crabs became completely narcotized and could easily be removed from their shells. The empty shells were shaken thoroughly and the entire sea water/alcohol was passed through a fine net $(120$ holes per $2.5 \mathrm{~cm})$. The copepods were picked from the sediment retained. The study of the copepods was carried out using the wooden slide/lactic acid technique described by Humes and Gooding (1964).

All figures have been drawn with the aid of a camera lucida. The letter after the explanation of each figure refers to the scale at which it was drawn. The measurements were made on specimens in lactic acid.

Sunaristes tranteri Hamond, 1973 (Figs. 1 - 5)

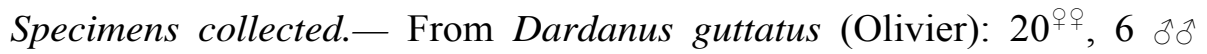
from 2 hosts, in $3 \mathrm{~m}$, Pulau Parang, eastern Ceram, $3^{\circ} 17^{\prime} 00^{\prime \prime S}, 130^{\circ} 44^{\circ} 48^{\prime \prime} \mathrm{E}$,

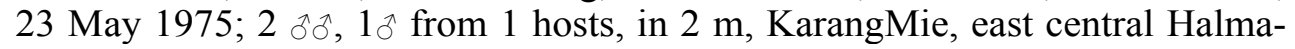
hera, 00²0'07"N, $128^{\circ} 25^{\prime} 00^{\prime \prime} \mathrm{E}, 19$ May 1975.

From Dardanus lagopodes (Forskal): 5 수, 1 क from 1 host, in $0.5 \mathrm{~m}$, southwestern shore of Goenoeng Api, Banda, 4³1'45"S, 129 51'55"E, 28 April 1975; 19 from 2 hosts, in 10 m, same locality, 4 May 1975; 10 99, 1 त from 1 host, in $15 \mathrm{~m}$, southwestern shore of Goenoeng Api, Banda, $4^{\circ} 31^{\prime} 55^{\prime \prime S}, 129^{\circ} 52^{\prime} 12^{\prime \prime E}, 8$ May 1975; 2 우, 1 o from 3 hosts, in $15 \mathrm{~m}$, same locality and date; 3 우 1 o from 1 host, in $3 \mathrm{~m}$, Pulau Marsegoe, western Ceram, $2^{\circ} 59$ WS, $128^{\circ} 03^{\prime} 30^{\prime \prime} \mathrm{E}, 15$ May 1975; 1 copepodid from 1 host, in $5 \mathrm{~m}$, Pulau Parang, eastern Ceram, $3^{\circ} 17^{\prime} 00^{\prime \prime S}, 130^{\circ} 44^{\prime} 48^{\prime \prime} \mathrm{E}, 23$ May 1975; 11 우 2 copepodids from 1 host, in $3 \mathrm{~m}$, Natsepa, Ambon, Ceram, 327'05"S, 128 1700"E, 28 May 1975. 
ARTHUR G. HUMES
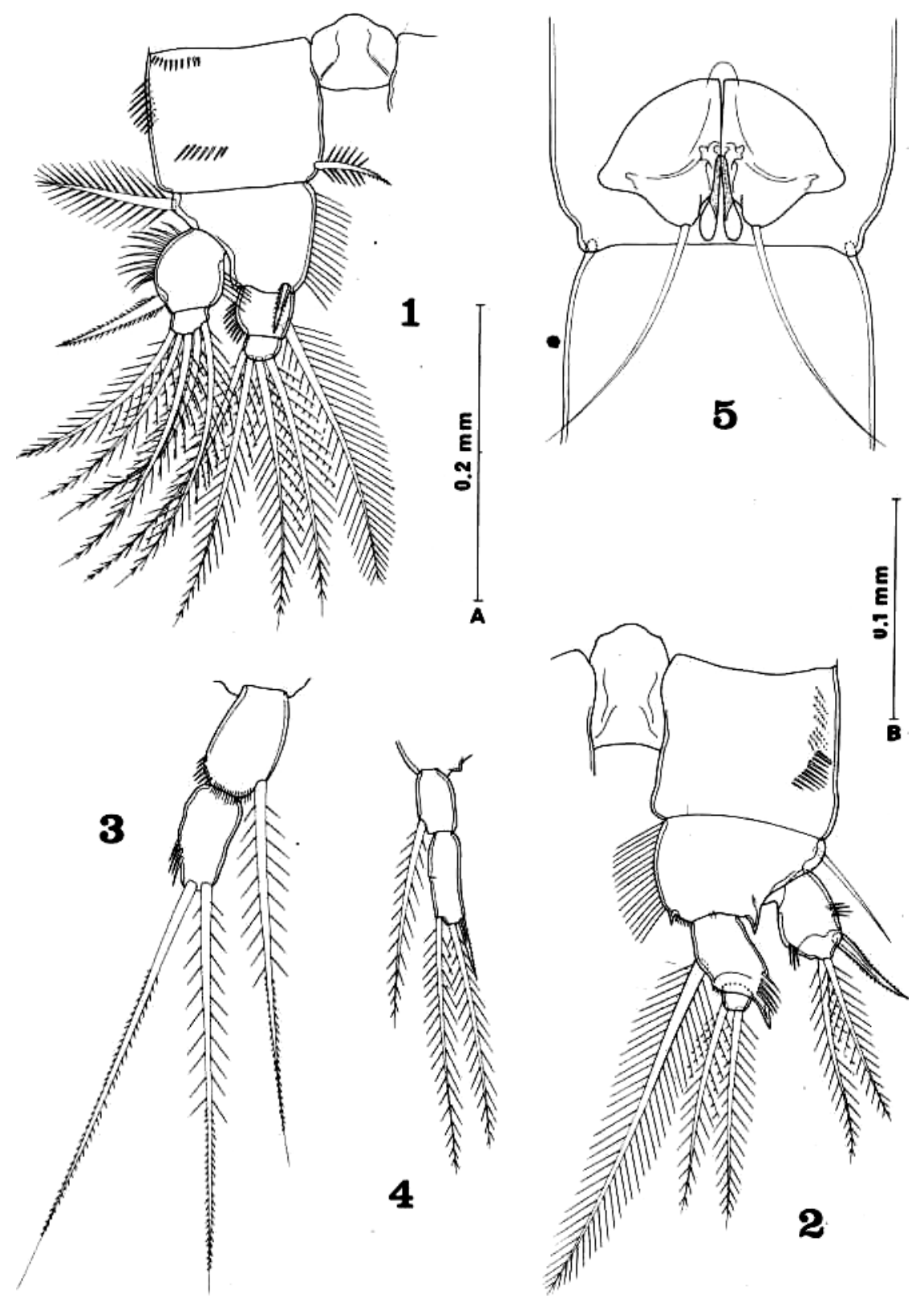

Figs. 1 - 5. Sunaristes tranteri Hamond, 1973. Female: 1, abnormal right leg 1, anterior (A); 2, abnormal left leg 2, anterior (A); 3, abnormal endopod of right leg 4, anterior (B). Male: 4, abnormal endopod of left leg 4, anterior (B); 5, genital area' ventral (B). 


\section{HARPACTICOID COPEPODS ASSOCIATED}

From Calcinus latens (Randall): $7 \stackrel{+ㅇ}{ }, 2$ 우, 2 copepodids from 8 hosts, in $15 \mathrm{~m}$, southwestern shore of Goenoeng Api, Banda, 4³1'55"S, 129 ${ }^{\circ}$ 52'12"E, 8 May 1975; $4^{\circ}, 8$ copepodids from 11 hosts, same locality and date.

From Calcinus minutus Buitendijk: 1 from 1 host, in $10 \mathrm{~m}$, southwestern shore of Goenoeng Api, Banda 4³1'45"S, 129 51'55"E, 4 May $1975 ; 1^{\circ}, 1$ o, 2 copepodids from 8 hosts, in $15 \mathrm{~m}$, southwestern shore of Goenoeng Api, Banda, 4³1'55"S, 12952'12"E, 8 May 1975.

From Calcinus gaimardi (H. Milne-Edwards): 299 from 1 host, in $10 \mathrm{~m}$, southwestern shore of Goenoeng Api, Banda, 4³1'45"S,12951'55"E, 4 May 1975.

From Calcinus sp., undescribed: $1^{\circ}, 1$ copepodid from 2 hosts, in 10m, southwestern shore of Goenoeng Api, Banda 4³1'45"S, 129 $51^{\circ} 55^{\prime \prime E}$, 4 May 1975.

From Trizopagurus strigatus (Herbst): 1 from 1 host, in $10 \mathrm{~m}$, southwestern shore of Goenoeng Api, Banda 4³1'45"S, 129 $51^{\prime} 55^{\prime \prime E}, 4$ May $1975 ; 5$ 우, 6 s $\delta^{1}$ from 4 hosts, in $15 \mathrm{~m}$, southwestern shore of Goenoeng Api, Banda, 431'55"S, 12952'12"E, 8 May 1975.

. The Moluccan specimens of Sunaristes tranteri conform in most respects to the original description of the type specimens from Sydney, Australia. The following notes are offered as a supplement to understanding the species.

Female.- The body length (measured on 63 specimens without pressure of a coverglass and not including the setae on the caudal rami) is $1.79 \mathrm{~mm}(1.28-2.00 \mathrm{~mm})$ and the greatest width is $0.33 \mathrm{~mm}(0.25-$ $0.41 \mathrm{~mm})$. The first antenna has probably five segments rather than six. There is a small sclerite immediately following the first segment which gives the illusion of a separate segment but which is actually part of the second segment. The formula is : 1, 14, $12+2$ aesthetes, 4 , and 14 . The inner (anterior) side of the first segment has a tuft of spinules. The second antenna has inner and outer tufts of spinules on the protopod. The exopod is 8 -segmented, with the formula : $1,0,1,1,1,1,1,4$. The endopod is 3-segmented, with the formula: 1, 4, 7.

The mandible has a tuft of spinules on the inner side of the second segment of the exopod.

The normal formula for legs $1-4$ is as follows : (abnormal formulae shown in parentheses):

$\begin{array}{llll}\text { leg } 1 & \operatorname{leg} 2 & \operatorname{leg} 3 & \text { leg } 4\end{array}$

exopod endopod exopod endopod exopod endopod exopod endopod

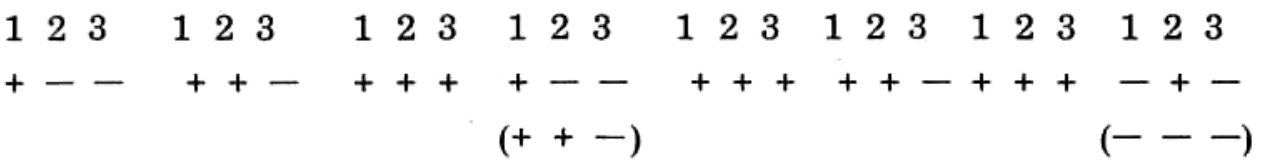




\section{ARTHUR G. HUMES}

Seven of 56 females (12.5 per cent) showed abnormal ornamentation. Leg 2 showed reduced segmentation in the right leg in one female (Fig. 1) and in the left leg in another female (Fig. 2). Leg 4 showed reduced segmentation in the right leg in one female (Fig. 3). The coxa of leg 4 does not bear spinules.

Male.- The body length (measured as in the female) is $1.41 \mathrm{~mm}(1.02$ $0.78 \mathrm{~mm})$ and the greatest width is $0.26 \mathrm{~mm}(0.19-0.33 \mathrm{~mm})$. The first antenna has the formula: $1,17,6,5$, and $5+3$.

The normal formula for legs $1-4$ is as follows (abnormal formulae shown in parentheses):

$\begin{array}{llll}\operatorname{leg} 1 & \operatorname{leg} 2 & \operatorname{leg} 3 & \operatorname{leg} 4\end{array}$ exopod endopod exopod endopod exopod endopod exopod endopod

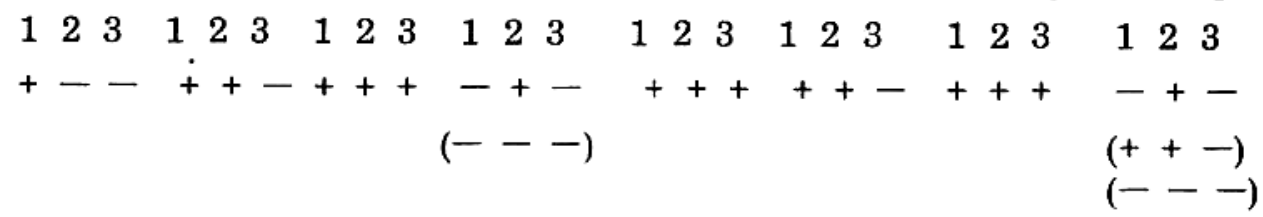

Five of 16 males (31.3 per cent) showed abnormal ornamentation. Leg 4 showed reduced segmentation in the left leg of one male (Fig. 4).

In leg 6 (Fig. 5) the two processes between the setae have broad hyaline tips.

Porcellidium brevicaudatum Thompson and A. Scott, 1903

Specimens collected - From Dardanusguttatus (Olivier): 19 우우, 13 ㅅํㅅ, 7 copepodids from 2 hosts, in $3 \mathrm{~m}$, Pulau Parang, eastern Ceram, $3^{\circ} 17^{\prime} 00^{\prime \prime S}$, $130^{\circ} 44^{\prime} 48^{\prime \prime E}, 23$ May 1975; 42 우, 32 ơ 33 copepodids from 1 host, in 2 $\mathrm{m}$, Karang Mie, east central Halmahera, 00²0'07"N, 128 $25^{\circ} 00^{\prime \prime} \mathrm{E} 19$ May 1975.

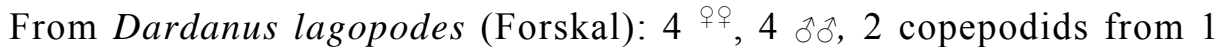
host, in $0.5 \mathrm{~m}$, southwestern shore of Goenoeng Api, Banda, 4 ${ }^{\circ} 31^{\prime} 45^{\prime \prime} \mathrm{S}$, 129 51'55"E, 28 April 1975; 10 우우 1 숭, 8 copepodids from 3 host, in 15 $\mathrm{m}$, southwestern shore of Goenoeng Api, Banda, 4³1'55"S, 129 $52^{\prime} 12^{\prime \prime} \mathrm{E}, 8$ May 1975; 3 후 , 11 तरํ, 20 copepodids from 1 host, Pulau Mar-segoe, western Ceram, 2 ${ }^{\circ} 59^{\prime} 30^{\prime \prime} \mathrm{S}, 128^{\circ} 03^{\prime} 30^{\prime \prime} \mathrm{E}, 15$ May 1975; 5 우, 3 o $^{\circ}$ froml host, in $5 \mathrm{~m}$, Pulau Parang, eastern Ceram, $3^{\circ} 17^{\prime} 00^{\prime \prime S}$, 130 44'48"E, 23 May 1975; 9 우, 21 수, 2 pairs in amplexus, 24 copepodids from 1 host, in $3 \mathrm{~m}$,

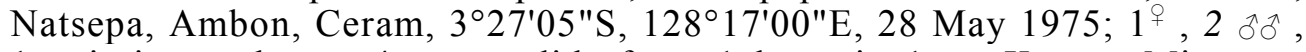
1 pair in amplexus, 4 copepodids from 1 host, in $1 \mathrm{~m}$, Karang Mie, east central Halmahera. $00^{\circ} 20^{\prime} 07^{\prime \prime} \mathrm{N}, 128^{\circ} 25^{\prime} 00^{\prime \prime} \mathrm{E}, 19$ May 1975. 


\section{HARPACTICOID COPEPODS ASSOCIATED}

From Dardanus megistos (Herbst): 31 우, 18 수 9 copepodids from 1 host, in $3 \mathrm{~m}$, Pulau Marsegoe, western Ceram, 2 ${ }^{\circ} 9^{\prime} 30^{\prime \prime} \mathrm{S}, 128^{\circ} 03^{\prime} 30^{\prime \prime} \mathrm{E}, 15$ May 1975.

From Calcinus latens (Randall): 13 우, 10 수 5 copepodids from 2 hosts, in $15 \mathrm{~m}$, southwestern shore of Goenoeng Api, Banda, 4'31'55"S, $129^{\circ} 52^{\prime} 12^{\prime \prime E}, 8$ May 1975.

From Calcinus minutus Buitendijk: 3 우, 4 수 from 8 hosts, in $15 \mathrm{~m}$, southwestern shore of Goenoeng Api, Banda, 431'55"S, 129 52'12"E, 8 May 1975; 1 + $20^{\circ}$ from 1 host, in $3 \mathrm{~m}$, Pulau Gomumu, south of Obi, $1^{\circ} 50^{\prime} 00^{\prime \prime} \mathrm{S}, 127^{\circ} 30^{\prime} 54^{\prime \prime} \mathrm{E}, 30$ May 1975.

From Trizopagurus strigatus (Herbst): $4 \stackrel{+\circ}{\circ}, 8^{\circ 0}, 2$ copepodids from 4 hosts, in $15 \mathrm{~m}$, southwestern shore of Goenoeng Api, Banda, 4³1'55"S, $129^{\circ} 5212^{\prime \prime E}, 8$ May 1975.

The Moluccan specimens are a little smaller than the specimens reported by Humes and Ho (1969) from Madagascar. The body length of 10 females from Dardanus guttatus at Pulau Parang is $0.63 \mathrm{~mm}(0.61-0.66$ $\mathrm{mm})$ and the greatest width is $0.44 \mathrm{~mm}(0.40-0.46 \mathrm{~mm})$. In 10 males the length is $0.43 \mathrm{~mm}(0.42-0.45 \mathrm{~mm})$ and the greatest width is $0.37 \mathrm{~mm}$ $(0.35-0.37 \mathrm{~mm})$. A female from the same species of host in Halmahera measured $0.74 \times 0.50 \mathrm{~mm}$. Except for such size differences the Moluccan specimens are like those previously studied from Madagascar.

\section{Paraidya minor Sewell, 1940 (Figs. 6 - 18)}

Specimens collected.- From Dardanusguttatus (Olivier): 53 우, 23 후, 8 copepodids from 2 hosts, in $3 \mathrm{~m}$, Pulau Parang, eastern Ceram, $3^{\circ} 17^{\prime} 00^{\prime \prime} \mathrm{S}$, $130^{\circ} 44^{\prime} 48^{\prime \prime E}, 23$ May 1975; 8 우, $15^{\circ}, 4$ copepodids from 1 host, in $2 \mathrm{~m}$, Karang Mie, east central Halmahera, $00^{\circ} 20^{\prime} 07^{\prime \prime} \mathrm{N}, 128^{\circ} 25^{\prime} 00^{\prime \prime} \mathrm{E}, 19$ May 1975.

From Dardanus megistos (Herbst): 10 우, 10 우, 8 copepodids from 1 host, in $3 \mathrm{~m}$, Pulau Marsegoe, western Ceram, 2 ${ }^{\circ} 59^{\prime} 30^{\prime \prime} \mathrm{S}, 128^{\circ} 03^{\prime} 30^{5} \mathrm{E}$, 15 May 1975.

From Dardanus lagopodes (Forskal): 4 우, 3 रुे from 1 host, in $1 \mathrm{~m}$, Karang Mie, east central Halmahera, 00²0'07"N, 128 25'00"E, 19 May 1975; 28 ㅇ $, 22^{30}, 17$ copepodids from 1 host, in $5 \mathrm{~m}$, Pulau Parang, eastern

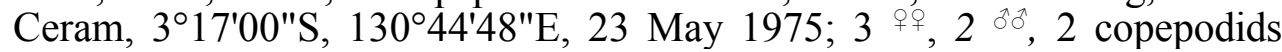
from 1 host, in 3m, Natsepa, Ambon, Ceram, 327'05"S, $128^{\circ} 17^{\prime} 00^{\prime \prime} \mathrm{E}, 28$ May 1975.

As a supplement to the original description of this copepod, which Sewell found in weed-washings at Nankauri Harbor, Nicobar Islands, certain features are described on the basis of Moluccan specimens. Those features 
ARTHUR G. HUMES

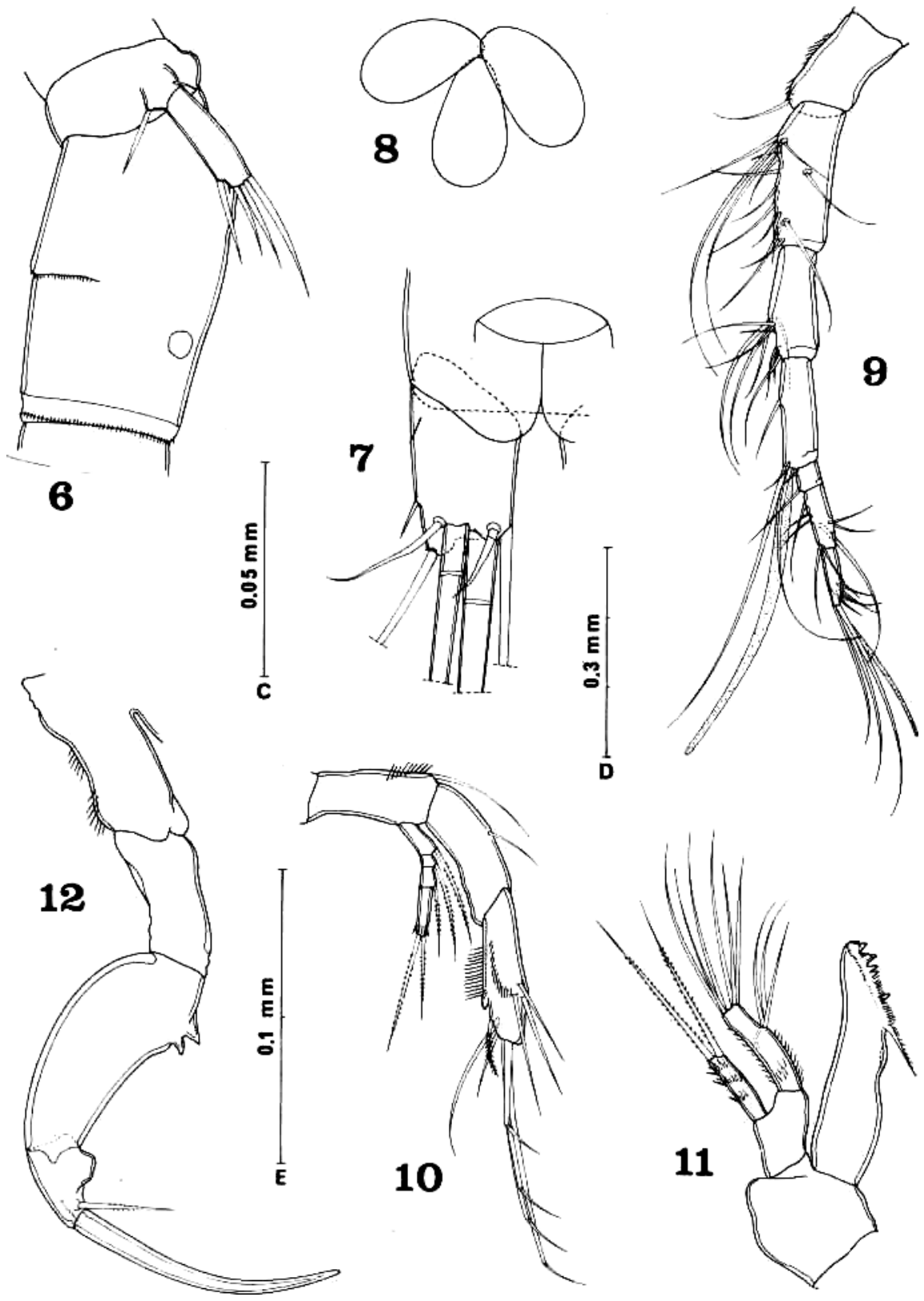

Figs $6-12$. Paraidya minor Sewell, 1940. Female : 6, segment of leg 5 and genital segment, lateral (B); 7, caudal ramus, dorsal (C); 8 , cluster of eggs, lateral (D); 9, first antenna, dorsal (B); 10, second antenna, posterior (E); 11, mandible, posterior (E); 12, maxilliped, posterior (E). 

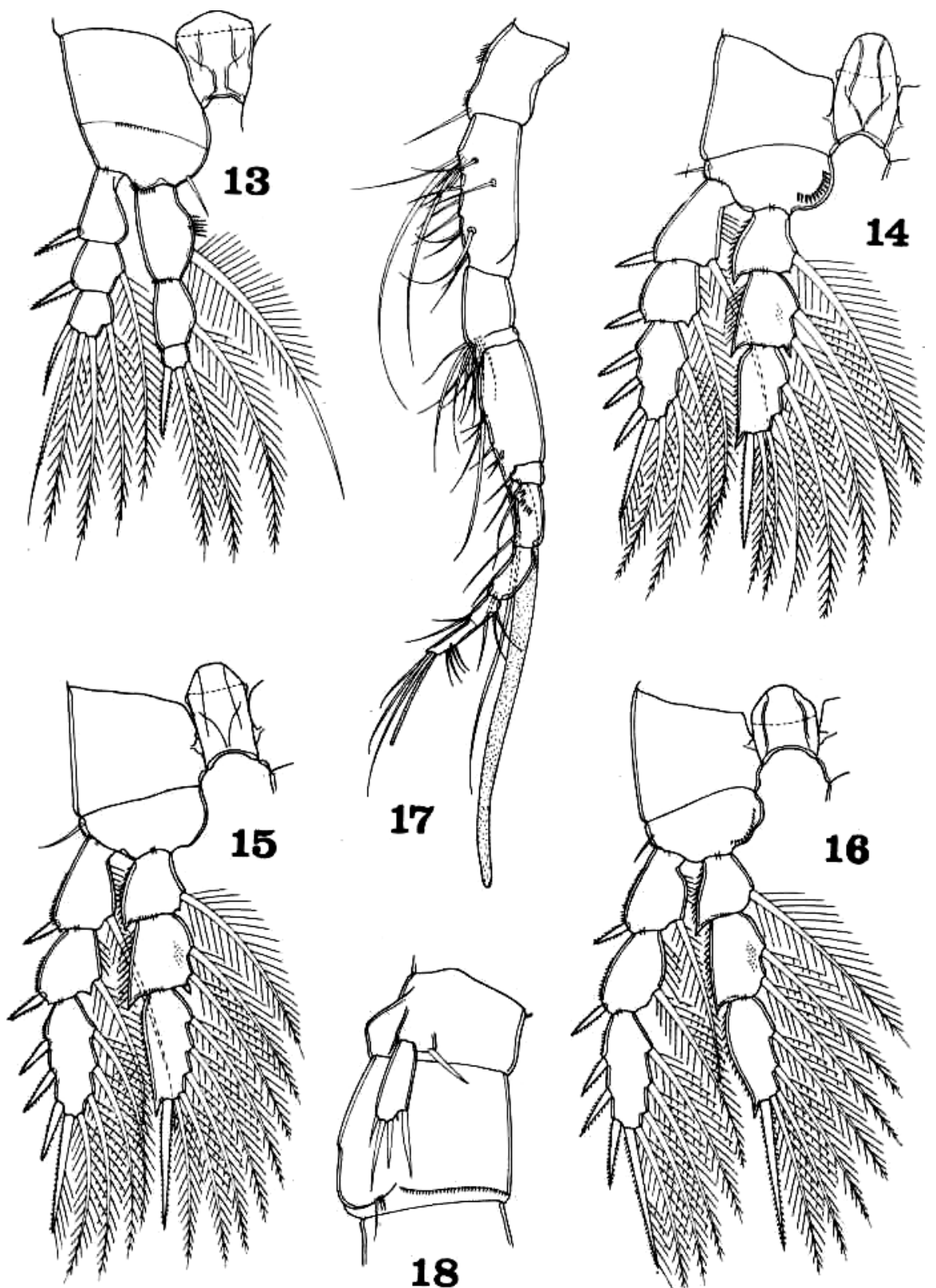

Figs. 13 - 18. Paraidya minor Sewell, 1940. Female : 13, leg 1 and intercoxal plate, anterior (B); 14, leg 2 and intercoxal plate, anterior (B); 15, leg 3 and intercoxal plate, anterior (B); 16, leg 4 and intercoxal plate, anterior (B). Male: 17, first antenna, dorsal (B); 18, segment of leg 5 and genital segment, lateral (B). 
not mentioned may be assumed to resemble closely those of Paraidya occulta Humes and Ho, 1969.

Female. - The length of the body (not including the setae on the caudal rami) is $0.79 \mathrm{~mm}(0.75-0.84 \mathrm{~mm})$ and the greatest width is $0.19 \mathrm{~mm}$. $(0.16-0.20 \mathrm{~mm})$, based on 10 specimens. In the posterior part of the genital segment there is a ventral internal round sclerotization (Fig. 6) which shows distinctly in specimens cleared in lactic acid. The genital and postgeni-tal segments have a posterior marginal fringe of small spinules. The caudal ramus (Fig. 7) is approximately $44 \times 26 \mu \mathrm{m}$ and lakes the inner marginal hairs shown in Sewell's Text - Fig. 14B. In addition to the six usual setae there is a small seta $12 \mu \mathrm{m}$ long on the outer margin of the ramus The outer seta (displaced dorsally) is $37 \mu \mathrm{m}$, the dorsal seta $23 \mu \mathrm{m}$, the outermost terminal seta $39 \mu \mathrm{m}$, and the innermost terminal seta $109 \mu \mathrm{m}$. All these setae are smooth. The two long median terminal setae, $295 \mu \mathrm{m}$ (outer) and $540 \mu \mathrm{m}$ (inner), are barbed along their midregions.

The eggs, usually three in a cluster (Fig. 8), occasionally two or four, are oval, $178 \mu \mathrm{m}(169-185 \mu \mathrm{m}) \times 97 \mu \mathrm{m}(96-101 \mu \mathrm{m})$.

The first antenna (Fig. 9) is $259 \mu \mathrm{m}$ long. The lengths of the seven segments (measured along their posterior nonsetiferous margins) are : 31 (38 $\mu \mathrm{m}$ along the anterior margin), 61, 46, 45, 11, 30, and $28 \mu \mathrm{m}$ respectively. The formula is : $1,15,10,4+1$ aesthete, 2,8 , and $7+1$ aesthete. All the setae are naked. The first segment bears anterior marginal spinules.

In the second antenna (Fig. 10) the protopod is $40 \mu \mathrm{m}$ long, the 2segmented endopod $88 \mu \mathrm{m}$, and the 4 -segmented exopod $35 \mu \mathrm{m}$. The protopod bears on its inner distal area a smooth seta and a row of hairs. The second endopod segment bears three smooth inner setae, four terminal smooth jointed setae, and three outer setae, two smooth and one conspicuously haired; this segment is ornamented with a posterior surficial crescentic row of spinules, outer marginal hairs, and a small outer process with minute spinules. The formula for the exopod is : 1, 1, 1, and 2, all the setae being minutely barbed. The fourth segment bears distally an anterior surficial row of spines.

Sewell's Text - Fig. 14A, labeled "rostrum", is evidently a drawing of the labrum.

In the mandible (Fig. 11) the endopod is relatively short, not reaching to the end of the corpus mandibulae. The maxilliped (Fig. 12) has two inner proximal conical processes on the second segment. The longer of the two setae on the third segment is minutely barbed. The claw is $81 \mu \mathrm{m}$.

Legs $1-4$ (Figs. 13-16) have details of ornamentation not shown in Sewell's Text - Fig. 14.

In leg 5 (Fig. 6) the small first segment bears a dorsal seta $30 \mu \mathrm{m}$ and a ventral seta $10 \mu \mathrm{m}$. The unornamented second segment is $47 \times 15.5 \mu \mathrm{m}$. Of the four setae one is subterminal and $39 \mathrm{Aim}$, the other three are terminal 


\section{HARPACTICOID COPEPODS ASSOCIATED}

and 36,42 , and $52 \mu \mathrm{m}$ from dorsal to ventral. A small setule $5 \mu \mathrm{m}$ arises between the subterminal seta and the terminal setae.

The color in life in transmitted light is opaque light brown, the eye red, and the eggs black.

Male. - The length of the body (measured as in the femael) is $0.71 \mathrm{~mm}$. $(0.69-0.73 \mathrm{~mm})$ and the greatest width $0.16 \mathrm{~mm}(0.16-0.17 \mathrm{~mm})$, based on 10 specimens. .The first antenna (Fig. 17) is $289 \mu \mathrm{m}$ long. The last segmment is very weakly subdivided. The lengths of the eight segments (measured as in the female) are: 33 (39 $\mu \mathrm{m}$. along the anterior edge), 68, 29, 53, 11, 29, 25 , and $35 \mu \mathrm{m}$ respectively. The formula is: $1,15,10,8+1$ aesthete, $2,2,2$, and $11+1$ aesthete. All the setae are smooth.

In leg 5 (Fig. 18) the two setae on the first segment are $27 \mu \mathrm{m}$ and 8 $\mu \mathrm{m}$. The unornamented second segment is $35 \mathrm{x} 14 \mu \mathrm{m}$ with the four setae from dorsal to ventral $33,22,33$, and $16 \mu \mathrm{m}$ respectively. All the setae are smooth. A small setule $5 \mu \mathrm{m}$ is found between the subterminal seta and the terminal setae.

The three setae of leg 6 (Fig. 18) are 9, 8, and $20 \mu \mathrm{m}$ from dorsal to ventral.

The color resembles that of the female.

\section{Paraidya major Sewell, 1940 (Figs. 19- 33)}

Specimens collected.- From Dardanus megistos (Herbst): 10 우 $, 5^{\hat{0} \hat{0}}, 1$ copepodid from 1 host, in $3 \mathrm{~m}$, Pulau Marsegoe, western Ceram, 2०59'30"S, $128^{\circ} 03^{\prime} 30^{\prime \prime E}, 15$ May 1975.

From Dardanus lagopodes (Forskal): $2^{\text {우 }}, 1^{\text {t }}$ from 1 host, in $3 \mathrm{~m}$, Pulau Marsegoe, western Ceram 2०59'30"S, 12803'30"E, 15 May 1975; 1 ${ }^{\circ}, 1^{\widehat{\delta}}, 2$ copepodids from 1 host, in $1 \mathrm{~m}$, Karang Mie, east central Halma-hera, $00^{\circ} 20^{\prime} 07^{\prime \prime} \mathrm{N}, 128^{\circ} .25^{\prime} 00^{\prime \prime E}, 19$ May $1975 ; 1^{+}, 2{ }^{\circ} 0^{\prime}$ from 1 host, in $5 \mathrm{~m}$, Pulau Parang, eastern Ceram, $3^{\circ} 17^{\prime} 00^{\prime \prime S}, 130^{\circ} 44^{\prime} 48^{\prime \prime E}, 23$ May 1975.

From Dardanus guttatus (Olivier): $4^{\circ+}, 2$ copepodids from 1 host, in 1 $\mathrm{m}$, Karang Mie, east central Halmahera, 00 $20^{\prime} 07^{\prime \prime N}, 128^{\circ} 25^{\prime} \mathrm{E}, 19$ May 1975.

In the partial redescription that follows features not mentioned may be assumed to resemble closely those of Paraidya occulta Humes and Ho, 1969.

Female, - The length of the body (excluding the setae on the caudal rami) is $1.37 \mathrm{~mm}(1.29-1.45 \mathrm{~mm})$ and the greatest width is $0.26 \mathrm{~mm}(0.23-$ $0.29 \mathrm{~mm}$ ), based on 10 specimens. The genital segment and the post-genital segments lack the posterior marginal fringe of small spinules seen in Paraidya minor. The caudal ramus (Fig. 19) is $83 \times 34 \mu \mathrm{m}$, ratio 2.44:1, 


\section{ARTHUR G. HUMES}

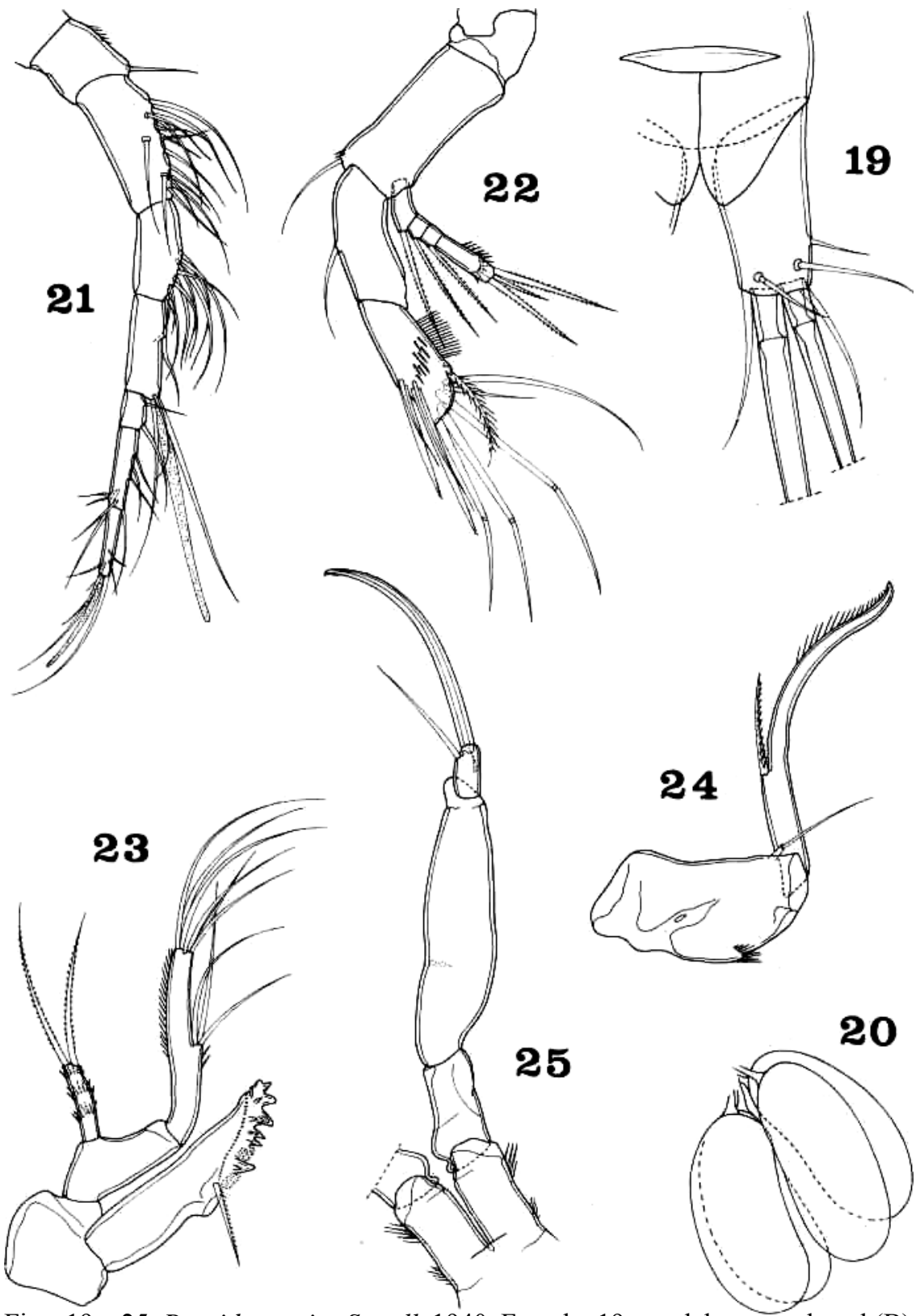

Figs. 19 - 25. Paraidya major Sewell, 1940. Female: 19, caudal ramus, dorsal (B);

20 , cluster of eggs, lateral (D); 21, first antenna, dorsal (A);22, second antenna, posterior (B); 23, mandible, posterior (B); 24, second maxilla, postero-inner (B) 25, maxilliped, posterior (A). 


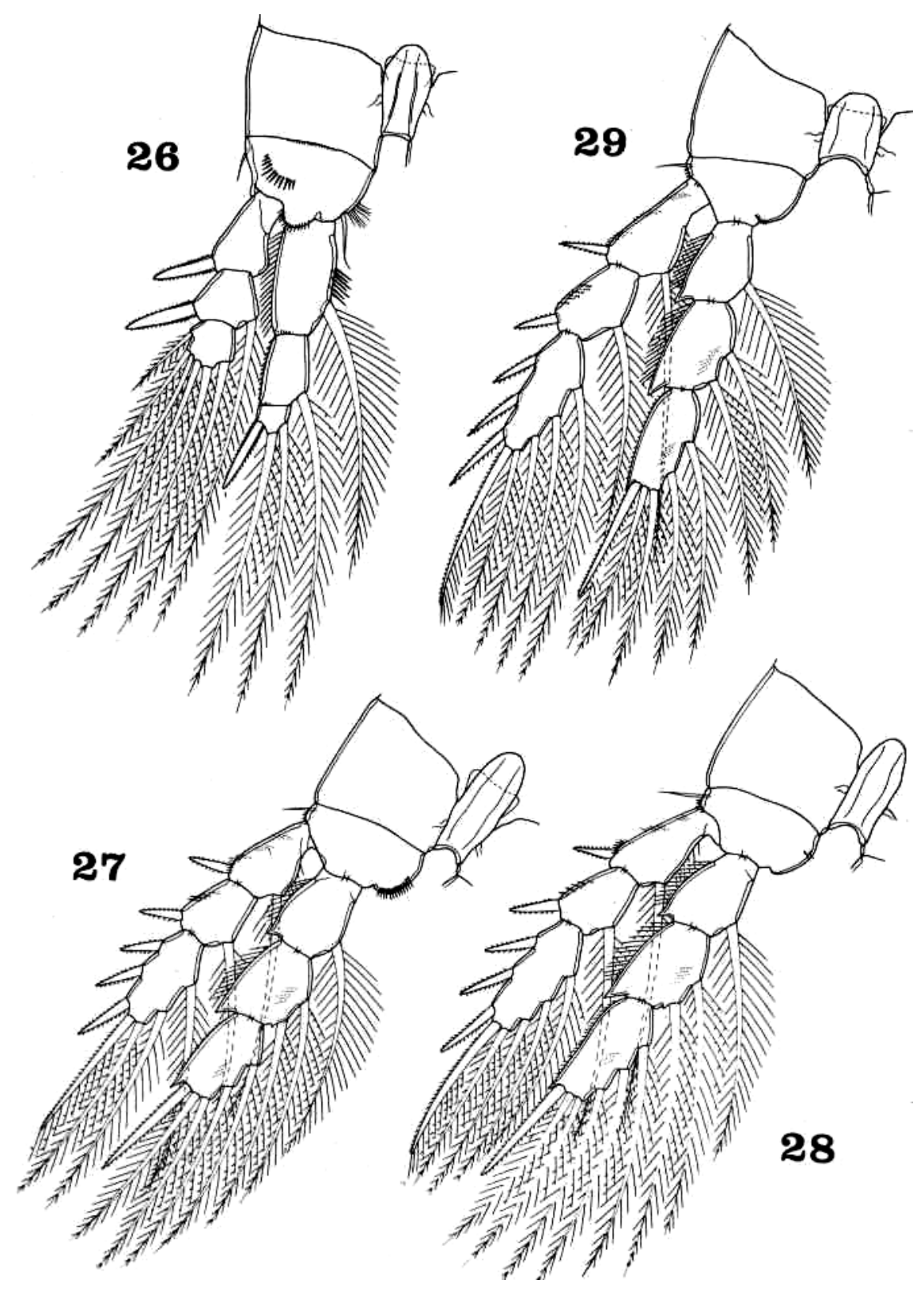

Figs. 26 - 29. Paraidya major Sewell, 1940. Female: 26, leg 1 and intercoxal plate (A); 27, leg 2 and intercoxal plate, anterior (A); 2,8, leg 3 and intercoxal plate, anterior (A); 29, leg 4 and intercoxal plate, anterior (A). 


\section{ARTHUR G. HUMES}
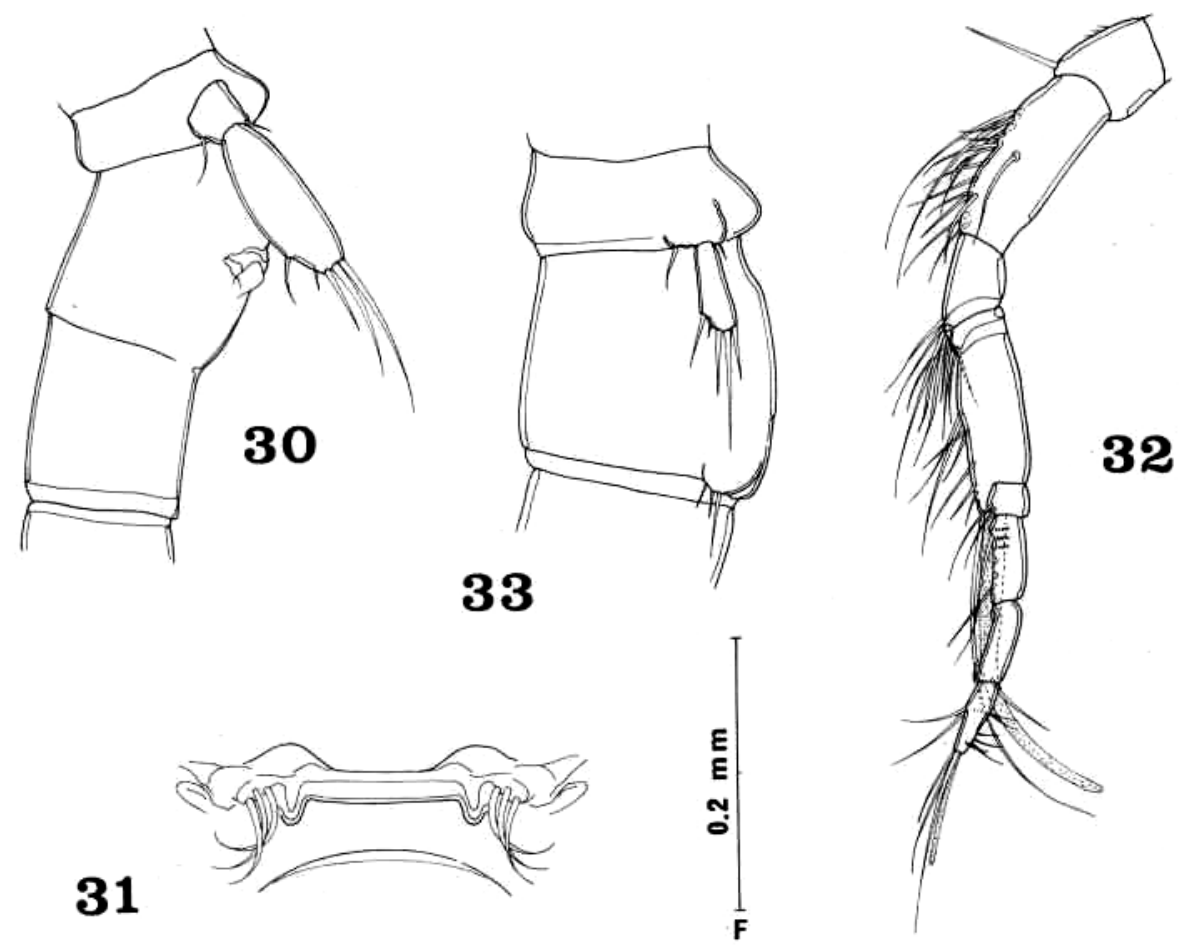

Figs. 30 - 33. Paraidya major Sewell, 1940. Female: 30, segment of leg 5 and genital segment, lateral $(\mathrm{F})$; 31, genital area, ventral (F). Male: 32, first antenna, dorsal (A); 33, segment of leg 5 and genital segment, lateral (A). 


\section{HARPACTICOID COPEPODS ASSOCIATED}

width taken at the level of the outer marginal seta. The outer seta (displaced dorsally) is $55 \mu \mathrm{m}$, the dorsal seta $30 \mu \mathrm{m}$, the outermost terminal seta $65 \mu \mathrm{m}$, and the innermost terminal seta $68 \mu \mathrm{m}$. All these setae are smooth. The two long median terminal setae, $500 \mu \mathrm{m}$ (outer) and $850 \mu \mathrm{m}$ (inner), have short barbs along their midregions. The small seventh seta on the outer margin of the ramus is $26 \mu \mathrm{m}$ and smooth.

The eggs, usually four in a cluster (Fig. 20), occasionally three, are elongate oval, $279 \mu \mathrm{m}(275-286 \mu \mathrm{m}) \times 122 \mu \mathrm{m}(121-126 \mu \mathrm{m})$.

The first antenna (Fig. 21) is $357 \mu \mathrm{m}$ Long. The lengths of the seven segments (measured along their posterior nonsetiferous margins) are: $39(52 \mu \mathrm{m}$ along the anterior margin), $81,49,58,23,49$, and $45 \mu \mathrm{m}$ respectively. The formula for the armature is like that of Paraidya minor. All the setae are smooth. The first segment bears a few anterior marginal spinules.

In the second antenna (Fig. 22) the protopod is $68 \mu \mathrm{m}$ long, the endopod $122 \mu \mathrm{m}$, and the exopod $57 \mu \mathrm{m}$. The terminal segment of the exopod bears three setae instead of two as in Paraidya minor. The lastsegment of the endopod bears 10 setae as in P. minor, but only three are jointed and two are stout with minute clawlike tips.

In the mandible (Fig. 23) the endopod is elongate, reaching well beyond the distal end of the corpus mandibulae. The second maxilla (Fig. 24) has a long smooth seta on the first segment.

The maxilliped (Fig. 25) lacks processes on the elongate second segment. The claw is $143 \mu \mathrm{m}$.

Legs $1-4$ (Figs. 26-29) show details in ornamentation not indicated in Sewell's Tex - Fig. 13.

In leg 5 (Fig. 30) the small first segment bears a dorsal seta $21 \mu \mathrm{m}$ and a ventral seta $13 \mu \mathrm{m}$. The second segment is $125 \mathrm{x} 44 \mu \mathrm{m}$, with smooth margins, not haired as shown in Sewell's Text - Fig. 13K. Of the four setae one seta is distinctly subterminal and $34 \mu \mathrm{m}$, the other three setae are terminal and 52, 96 , and $120 \mu \mathrm{m}$ respectively from dorsal to ventral, A small setule $13 \mu \mathrm{m}$ arises between the subterminal seta and the terminal setae. All the setae are smooth.

Leg 6 (Fig. 31) is represented in the genital field by three equal smooth setae approximately $27 \mu \mathrm{m}$.

The color in life in transmitted ligth resembles that of Paraidya minor.

Male. - The length of the body (measured as in the female) is $1.08 \mathrm{~mm}$ $(0.94-1.18 \mathrm{~mm})$ and the greatest width is $0.21 \mathrm{~mm}(0.19-0.22 \mathrm{~mm})$, based on seven specimens. The first antenna (Fig. 32) is $389 \mu \mathrm{m}$ long. The lengths of the eight segments (measured as in the female) are : 30 (48/am along the anterior margin), $88,34,78,18,42,42$, and $39 \mu \mathrm{m}$ respectively. The sixth segment has three rows of spinules on its dorsal surface. The aesthete on the fourth segment is shorter than in Paraidya minor. The third segment has a dorsal bandlike sclerite giving a false appearance of a segment. 


\section{ARTHUR G. HUMES}

This sclerite, however, is not present on the ventral surface of the segmnet. The formula for the armature is like that in Paraidya minor. All the setae are smooth.

In leg 5 (Fig. 33) the two setae on the first segment are $19 \mu \mathrm{m}$ and 6 $\mu \mathrm{m}$. The second segment is $44 \times 17 \mu \mathrm{m}$ with the four setea $29,39,62$, and $27 \mu \mathrm{m}$ from dorsal to ventral. A small setule $5 \mu \mathrm{m}$ is located between the dorsal subterminal seta and the terminal setae. All the setae are smooth.

The three setae on leg 6 (Fig. 33) are 15, 15, and $39 \mu \mathrm{m}$ from dorsal to ventral.

The color is similar to that of the female.

Remarks. - The four harpacticoid genera known from Paguridea have different numbers of species living with these crustacean inhabitants of gastropod shells. Species of the genus Sunaristes live with hermit crabs "in Europe (including the Mediterranean Sea and the Black Sea) and in the Indian Ocean and the western half of the Pacific Ocean. Only one species of the large genus Porcellidium (containing numerous species) lives with hermit crabs. $P$. brevicaudatum occurs commonly with these hosts in the Indian Ocean and the western Pacific Ocean. Three species of Brianola living with Diogenes in Australia became known as a result of recent work of Hamond (1973). The genus Paraidya contains three species associated with hermit crabs in Madagascar and the Moluccas. It is possible that Sewell's type specimens of Paraidya minor and Paraidya major found in the Nicobar Islands in weedwashings may have been dislodged from shells inhabited by hermit crabs.

A list of the Paguridea in the Indo-Pacific known to have associated harpacticoid copepods follows.

Indo-Pacific Paguridea and their associated harpacticoid copepods

Calcinus gaimardi (H. Milne-Edwards)

Sunaristes tranteri Calcinus latens (Randall)

Porcellidium brevicaudatum

Sunaristes dardani

Sunaristes inaequalis

Sunaristes tranteri Calcinus minutus Buitendijk

Porcellidium brevicaudatum

Sunaristes tranteri Calcinus sp., undescribed

Sunaristes tranteri Clibanarius carnifex Heller

Sunaristes inaequalis 
Clibanarius virescens Krauss

\section{HARPACTICOID COPEPODS ASSOCIATED}

Porcellidium brevicaudatum

Sunaristes dardani

Sunaristes inaequalis

Dardanus deformis (H. Milne-Edwards)

Porcellidium brevicaudatum

Sunaristes dardani Dardanus guttatus (Olivier)

Paraidya major

Paraidya minor

Porcellidium brevicaudatum

Sunaristes dardani

Sunaristes tranteri Dardanus lagopodes (Forskal)

Paraidya major

Paraidya minor

Porcellidium brevicaudatum

Sunaristes dardani

Sunaristes tranteri Dardanus megistos (Herbst)

Paraidya major

Paraidya minor

Paraidya occulta

Porcellidium brevicaudatum

Sunaristes dardani

Sunaristes inaequalis Dardanus scutellatus

Porcellidium brevicaudatum

Sunaristes dardani

Sunaristes inaequalis Diogenes senex

Brianola elegans

Brianola pori

Brianola sydneyensis

Sunaristes tranteri

Pagurus novaezealandiae Filhol

Sunaristes sp., undescribed Pagurus sp.

Porcellidium brevicaudatum Trizopagurus strigatus

(Herbst)

Porcellidium brevicaudatum

Sunaristes tranteri 


\section{ARTHuR G. HumES CONCLUSIONS}

Hermit crabs in the Indo-Pacific, and especially in the Moluccas, may be expected to have several species of harpacticoid copepods associated with them. These include Sunaristes dardani Humes and Ho, 1969, Sunaristes inaequalis Humes and Ho, 1969, Sunaristes tranteri Hamond, 1973, Brianola elegans Hamond, 1973, Brianola pori Hamond, 1973, Brianola sydney-ensis Hamond, 1973 Porcellidium brevicaudatum Thompson and A. Scott, 1903, Paraidya occulta Humes and H, 1969, Paraidya major Sewell, 1940, and Paraidya minor Sewell, 1940.

\section{ACKNOWLEDGEMENTS}

The four species of harpacticoids reported from various hermit crabs in the Moluccas were collected by the author during the Alpha Helix East Asian Bioluminescence Expedition, which was supported by the National Science Foundation under grants OFS 7401830 and OFS 7402888 to the Scripps Institution of Oceanography and grant MBS 7423242 to the University of California, Santa Barbara.

I am much indebted to Dr. Janet Haig, Allan Hancock Foundation, for the identifications of the hermit crabs. I also thank Mr. Thomas Forhan, who, by SCUBA diving, collected hermit crabs in water too deep for diving with snorkel.

\section{REFERENCES}

Claus, C. 1860. Beitraege zur Kenntniss der Entomostraken, 1: 1 - 28. (Marburg, Germany).

CodreAnu, R. and V. Mack-Fira 1961. Sur un Copepode, Sunaristes paguri Hesse 1867 et un Polychete, Polydora ciliata (Johnston) 1838, associes au Pagure Diogenes pugilator (Roux) dans la Mer Noire et la Mediterranee. La notion de cryp-totropisme. Rapp. Comm. Int. Explor. Sci. Mer Medit 16:471 - 494.

HAMOND, R. 1973. Four new copepods (Crustacea: Harpacticoida, Canuellidae) simultaneously occurring with Diogenes senex (Crustacea: Paguridae) near Sydney, Proc. Linn. Soc. New South Wales 97: $165-201$.

Hesse, M. 1867. Observations sur des Crustaces rares ou nouveaux des cotes de France. Ann. Sci. Nat., (5) (Zool. Paleontol.) 7 : $199-216$.

Humes, A.G. 1971. Sunaristes (Copepoda, Harpacticoida) associated with hermit crabs at Eniwetok Atoll. Pac. Sci. 25 : $529-532$.

Humes, A.G. 1972. Sunaristes and Porcellidium (Copepoda, Harpacticoida) associated with hermit crabs in New Caledonia. Cah. O.R.S.T.O.M., ser. Oceanogr. 10:263-266

Humes, A.G. and R.U. Gooding 1964. A method for studying the external anatomy of copepodes. Crustaceana $6: 238-240$.

HumES, A.G. and J. - S. Ho 1969a. The genus Sunaristes (Copepoda, Harpacticoida) associated with hermit crabs in the western Indian Ocean.Crustaceana $17: 1$ - 18. 


\section{HARPACTICOID COPEPODS ASSOCIATED}

Humes, A.G. and J. - S. Ho 1969b. Harpacticoid copepods of the genera Porcellidium and Paraidya associated with hermit crabs in Madagascar and Mauritius. Crustaceana 17 : $113-130$.

LANG, K. 1948. Monographic der Harpacticiden. 2 vols.: 1 - 1682. (Lund, Sweden).

MonARD, A. 1926., Note sur la faune des harpacticoides marins de Cette. Arch. Zool Exp. Gen. $65: 39-54$.

ScotT, A. 1909. The Copepoda of the Siboga Expedition. I. Free-swimming, littoral and semiparasitic Copepoda. Siboga Exped. Monogr. 29a 1-323.

Sewell, R.B.S. 1940. Copepoda Harpacticoida. John Murray Exped. 1933-34, Sci. Repts. 7 : 117- 382 .

Stock, J.H. 1960. Sur quelques Copepodes associes aux invertebres des cotes du Rousillon. Crustaceana $1: 218-257$.

Thompson, I.C. and A. ScOTT 1903. Report on the Copepods collected by Professor Herdman, at Ceylon, in 1902. Rept. Govt. Ceylon Pearl Oyster Fish. Gulf of Manaar 1 (Suppl. Rept 7) : $227-307$. 